International Research Journal of Management, IT \& Social Sciences
Available online at https://sloap.org/journals/index.php/irjmis/
Vol. 6 No. 3, May 2019, pages: 18 28
ISSN: 2395-7492
https://doi.org/10.21744/irjmis.v6n3.624

\title{
The Role of Working Experience Moderating the Effect of Emotional Intelligence, Intellectual Intelligence, and Spiritual Intelligence on the Ethical Decision of Tax Consultants in Bali Area
}

I Putu Indra Wiguna

Ketut Yadnyana ${ }^{\mathrm{b}}$

Article history:

Received: 27 December 2018

Accepted: 31 March 2019

Published: 24 April 2019

\section{Keywords:}

emotional intelligence;

ethical decisions;

intellectual intelligence;

spiritual intelligence;

work experience;

\begin{abstract}
This study aims to examine the effect of emotional intelligence, intellectual intelligence, and spiritual intelligence on ethical decisions of tax consultants with work experience as moderating variables. The population in this study were all registered tax consultants in the Bali Region who had practice licenses in accordance with the Directory of Indonesian Tax Consultants Association in 2018 as many as 58 people. The research sample was determined by purposive sampling method and based on the specified criteria obtained a total sample of 41 people. Research data was collected through survey methods with questionnaire techniques. The data analysis technique used in the study was multiple linear regression analysis and moderated regression analysis. The results showed that the variables of emotional intelligence had a positive effect on ethical decisions, intellectual intelligence had a positive effect on ethical decisions, and spiritual intelligence had a positive effect on ethical decisions. Work experience moderates the effect of emotional intelligence, intellectual intelligence, and spiritual intelligence on the ethical decisions of tax consultants.
\end{abstract}

2395-7492@ Copyright 2019. The Author. This is an open-access article under the CC BY-SA license (https://creativecommons.org/licenses/by-sa/4.0/) All rights reserved.

\section{Author correspondence:}

I Putu Indra Wiguna,

Faculty of Economic and Business Udayana University, Bali, Indonesia.

Email address: indra.wiguna89@gmail.com

\section{Introduction}

Devos (2012), states taxpayers use tax consultants to represent them for a number of reasons. That is: the desire to report accurate tax returns mainly due to their lack of knowledge of taxes based on the complexity of current tax law, the desire to minimize their taxes in an ethical manner required to be paid, and their fear of making mistakes that can

a Faculty of Economic and Business, Udayana University, Bali, Indonesia

${ }^{\mathrm{b}}$ Faculty of Economic and Business, Udayana University, Bali, Indonesia 
lead to sanctions, Pitaloka \& Ardini (2017), state that ethical decision making by tax consultants is needed in order to gain public trust in the quality of the profession. A tax consultant in making ethical decisions will use more than one rational consideration based on the ethical values he understands and make a fair decision and the actions taken can reflect the truth or the actual situation (Arestanti et al., 2016). A tax consultant who adheres to the code of ethics in carrying out his profession is effect by several factors, namely individual factors, organizational factors, and psychological factors. Some of the factors that affect the performance of a tax consultant who comes from within themselves and is human psychological elements are emotional intelligence, intellectual intelligence, and spiritual intelligence (Mahadewi et al., 2015).

Goleman (2005), suggests that ethical behavior can be effect by intellectual intelligence and emotional intelligence where twenty percent of an individual's success is determined by intellectual intelligence and the remaining eighty percent is determined by emotional intelligence. The statement was supported by Durgut et al., (2013), which revealed that success is not only based on emotional intelligence but also requires intellectual intelligence. Emotional intelligence directs a person's ability in terms of self-recognition, self-control, motivation, empathy, and social skills. A tax consultant requires emotional intelligence in dealing with tax problems for his clients both in terms of tax consultations and when conducting checks in order to analyze the truth of making tax reports by clients. This is in line with the research conducted by Wijayanti (2012) which states that emotional intelligence will make it easier for an auditor to conduct an examination, have strong motivation, self-control/emotion, empathy, and socialization skills will assist the auditor in tracing the evidence audit and related information.

In addition to ethical standards that must be renewed, one of the main components in overcoming ethical dilemmas towards a profession is through religious emphasis or aspects of spiritualism (Ljubomir \& Angelina, 2015). Spiritual intelligence is intelligence to deal with and solve problems of meaning and value that place behavior and human life in a broader context that enables one to unite things that are intrapersonal and interpersonal, and bridge the gap between oneself and others (Agustini, 2013) According to Suadnyana (2015), an accountant will find it difficult to direct thoughts and actions in accordance with the professional code of ethics that apply if they do not have emotional maturity, logical abilities, and belief in God Almighty. The tax consultant profession requires a high understanding of emotional intelligence, intellectual intelligence, and spiritual intelligence in order to be able to apply ethical actions and behavior in his profession and organization. A tax consultant who does not have emotional intelligence, intellectual intelligence, and high spiritual intelligence will allow tax consultants to conduct unethical behavior for example because they are affected by large rewards from clients, namely tax consultants are willing to be dishonest by manipulating financial statements in order to minimize taxes that should be paid to the state. Farrastama et al. (2019), tax consultant profession is a profession that is required to have integrity and honesty in order to be objective so that spiritual intelligence can be used as a foundation used to function intellectual intelligence and emotional intelligence effectively. In brief, spiritual intelligence is able to integrate two other previously mentioned abilities, namely intellectual intelligence and emotional intelligence (Mahadewi et al., 2015).

Several studies related to ethical research have been carried out and have shown inconsistent results. Research results of Abdurrahman \& Yuliani (2011); Uyar \& Özer (2011); and Doyle et al., (2014). Found that ethical orientation had a significant effect on ethical decision making. The results of the Suardika (2015), found that idealism, professional commitment, and professional skepticism had a significant effect on the ethical decisions of tax consultants in the Bali Region. The results of the Tikollah (2006); Mahadewi et al., (2015), and Agustini (2013), found intellectual intelligence had an effect on ethical behavior. Atmaja \& Saputra (2014) states that emotional intelligence and spiritual intelligence have a significant effect on the ethical behavior of the accounting profession. Mianingsih (2011), concluded that emotional intelligence and intellectual intelligence affect the making of ethical decisions related to accounting information systems, while spiritual intelligence does not affect the ethical decisions of accounting information systems. The research results of Lucyanda (2013) and Kurniasari (2016), found intellectual intelligence and emotional intelligence did not affect ethical decisions,

The inconsistency of some of the results of previous studies led to the use of contingency approaches to resolving differences in the results of these studies. The contingency approach allows for other independent variables or moderating variables that can affect the relationship between emotional intelligence, intellectual intelligence, and spiritual intelligence with ethical decisions (Jogiyanto, 2014). The moderating variable used in this study is work experience. Research conducted by Treviño (1986), revealed that ethical decision-making behavior is effect by factors that are uniquely the result of the process of socialization and development of a decision maker, one of which is work experience. Similarly, in the world of other accounting professions, a tax consultant develops its potential based on experience gained through discussion, training, and the use of codes of ethics. Experienced tax consultants are usually

Wiguna, I. P. I., \& Yadnyana, K. (2019). The role of working experience moderating the effect of emotional intelligence, intellectual intelligence, and spiritual intelligence on the ethical decision of tax consultants in Bali area. 
more conservative when facing ethical dilemmas. Owned work experience has an impact on every decision taken by a tax consultant so that every decision taken is expected to be the right and ethical decision. This indicates that the more experience gained by the tax consultant, the better the decisions produced. Specifically, the measurement of experience can be done by knowing the position, length of work, increasing expertise, and training that has been followed (Sukriyah et al., 2009).

The theory of cognitive moral development concludes that the stages of moral development are a measure of one's moral height based on the development of moral reasoning as expressed by Kohlberg (1971). Kohlberg (1971), suggested that a person's moral value would increase as more experiences were encountered during his lifetime. This is supported by the research of Suraida (2005), who found that audit experience and competency had an effect on the accuracy of the opinion of auditors of public accountants, as was the case with the results of Sukriyah et al., (2009), who found that work experience can improve the quality of the results of auditor audits. Therefore, the researcher tried to add this research with the moderating work experience variables that the researcher assumed could strengthen or weaken the relationship between the variables of intellectual intelligence, emotional intelligence and spiritual intelligence on ethical decision variables. Based on the explanation above, the researcher is interested in examining the effect of emotional intelligence, intellectual intelligence, and spiritual intelligence on ethical decisions of tax consultants in Bali Province by adding work experience as a moderating variable.

\section{Literature Review}

The Effects of Emotional Intelligence on Ethical Decisions $\backslash$

Emotional intelligence is needed by tax consultants because they must be able to control, understand, and identify their emotions in a way that enables them to communicate well, identify the problems they face, form relationships, and maintain their relationships with many people both inside and outside the work environment. Running a profession as a tax consultant will certainly be faced with various cases and challenges that must be faced such as in completing the demands of the task and relations with other people both with clients and others. Solving these problems requires emotional intelligence that is high in managing emotions in order to determine the right decision. The results of the study by Mahadewi et al., (2015), showed that emotional intelligence had a positive effect on one's ethical behavior and Tikollah (2006) and Mianingsih (2011), research showed that emotional intelligence had a positive effect on ethical decisions. Based on the description, a hypothesis can be drawn:

H1: Emotional intelligence has a positive effect on the ethical decisions of tax consultants in the Bali Region.

\section{The Effect of Intellectual Intelligence on Ethical Decisions}

Dwijayanti (2009), states that intellectual intelligence as an ability consists of three characteristics, namely the ability to direct the mind, the ability to control actions, and the ability to self-criticize. Robins \& Judge (2008), states that intellectual intelligence is the ability needed to perform various mental activities to think and solve problems. Yani (2011), formulates that intellectual intelligence is the ability to obtain, recall, and use knowledge to understand abstract and concrete concepts and the relationship between objects and ideas and apply knowledge appropriately. A tax consultant requires high intellectual intelligence in order to be able to show knowledge about the problems faced, analyze the conditions so that they can determine the right decision for their clients. High intellectual intelligence can direct tax consultants to make ethical decisions. Some studies on the effect of intellectual intelligence on ethical decisions show positive results, including research by Mahadewi et al., (2015); Tikollah (2006) and Mianingsih (2011). Based on the description, a hypothesis can be drawn:

$\mathrm{H} 2$ : Intellectual intelligence has a positive effect on the ethical decisions of tax consultants in the Bali Region.

\section{The Effect of Spiritual Intelligence on Ethical Decisions}

Tax consultant profession is a profession that is required to have integrity and honesty to be objective. Therefore spiritual intelligence is the foundation needed to effectively function intellectual intelligence and emotional intelligence. Briefly, spiritual intelligence is able to integrate two other abilities that have previously been mentioned, namely intellectual intelligence and emotional intelligence. Therefore people who have high spiritual intelligence can make ethical decisions in solving problems. Several studies on the effect of spiritual intelligence on ethical decisions have shown positive results, including research in Tikollah (2006) and Lisda (2009). Based on the description, a hypothesis can be drawn: 
H3: Spiritual intelligence has a positive effect on the ethical decisions of tax consultants in the Bali Region.

\section{The Work Experience Moderating the Effects of Emotional Intelligence on Ethical Decisions}

A tax consultant who has high flight hours will certainly have good moral values by understanding and implementing the rules in accordance with the code of ethics established by the profession, understanding the actions taken, and working calmly because they have knowledge of qualified knowledge, so that tax consultants who have a high level of experience tend to determine decisions that are more ethical than tax consultants who have less work experience. A tax consultant who has a lot of experience tends to have a high level of emotional intelligence because a learning process from problems and cases he has faced in the field is certainly more than a tax consultant who has little experience so that decisions made can be more ethical. This is supported by research by Harmana et al., (2017). which shows that the experience level of tax consultants effects the ethical decision making of tax consultants and Syarhayuti (2016), shows that specific understanding gained from audit experience will affect performance in audit assignments. Audit assignments also include audit decision making. Based on the description, a hypothesis can be drawn:

H4: Work experience strengthens the effect of emotional intelligence on the ethical decisions of tax consultants in the Bali Region.

\section{The Work Experience Moderating the Effect of Intellectual Intelligence on Ethical Decisions}

A tax consultant who has a high level of work experience will certainly have good moral values by understanding and implementing the rules in accordance with the code of ethics established by the profession, understanding the actions taken, and working calmly because they have qualified science, so that tax consultants who have a high level of experience tend to determine decisions that are more ethical than tax consultants who have less work experience. A tax consultant who has a lot of experience tends to have a high level of intellectual intelligence because a learning process from problems and cases he has faced in the field is certainly more than a tax consultant who has little experience so that decisions made can be more ethical. This is supported by research by Harmana et al., (2017), which shows that the experience level of tax consultants effects the decision making of tax consultants and the research of Syarhayuti \& Adziem (2016), shows that special understanding gained from audit experience will affect the quality of performance in audit assignments. Audit assignments also include audit decision making. Based on the description, a hypothesis can be drawn:

H5: Work experience strengthens the effect of intellectual intelligence on the ethical decisions of tax consultants in the Bali Region.

\section{The Work Experience Moderating the Effect of Spiritual Intelligence on Ethical Decisions}

A tax consultant who has high flight hours will certainly have good moral values by understanding and implementing the rules in accordance with the code of ethics established by the profession, understanding the actions taken, and working calmly because they have knowledge of qualified knowledge, so that tax consultants who have a high level of experience tend to determine decisions that are more ethical than tax consultants who have less work experience. A tax consultant who has a lot of experience tends to have a high level of spiritual intelligence because a learning process of problems and cases he has faced in the field is certainly more than a tax consultant who has little experience so that decisions made can be more ethical. This is supported by research by Harmana et al., (2017), which shows that the experience level of tax consultants affects the decision making of tax consultants and the research of Syarhayuti \& Adziem (2016), shows that special understanding gained from audit experience will affect the quality of audit assignments. Audit assignments also include audit decision making. Based on the description, a hypothesis can be drawn:

H6: Work experience strengthens the effect of spiritual intelligence on ethical decisions of tax consultants in the Bali Region.

Wiguna, I. P. I., \& Yadnyana, K. (2019). The role of working experience moderating the effect of emotional intelligence, intellectual intelligence, and spiritual intelligence on the ethical decision of tax consultants in Bali area. International Research Journal of Management, IT and Social Sciences, 6(3), 18-28. 


\section{Materials and Methods}

This research was conducted in 2018 at the Tax Consultant Office in the Bali Region. Based on the source, the type of data used in this study is primary data collected through survey methods with questionnaire techniques in the form of statements and cases related to emotional intelligence, intellectual intelligence, spiritual intelligence, work experience, and ethical decisions. Based on its nature, the data used in this study is quantitative data which includes the score data of the collected questionnaire answers. The population in this study were all registered tax consultants in the Bali Region who had practice permits in accordance with the Indonesian Tax Consultant Association Directory in 2018. The sampling technique used in this study was purposive sampling. This study uses verification data analysis techniques using multiple linear regression and Moderated Regression Analysis (MRA). Testing the hypothesis one, second, and third (H1, H2, H3) is tested by looking at the value of t value or p-value.

\section{Results and Discussions}

The test results of the influence of emotional intelligence, intellectual intelligence, and spiritual intelligence on ethical decisions that are moderated by work experience variables can be seen in Table 1 .

Table 1

Moderation Testing Result

\begin{tabular}{|c|c|c|c|c|c|}
\hline \multirow[t]{2}{*}{ Variabel } & Unstandardized & Coefficient & $\begin{array}{c}\text { Standardized } \\
\text { Coefficient }\end{array}$ & t-hitung & Sig. \\
\hline & B & Std. Error & Beta & & \\
\hline Constant & 5,032 & 3,990 & & 1,261 & 0,216 \\
\hline $\mathrm{X} 1$ & 0,545 & 0,539 & 2,971 & 1,011 & 0,001 \\
\hline $\mathrm{X} 2$ & 0,389 & 0,765 & 0,936 & 0,508 & 0,002 \\
\hline $\mathrm{X} 3$ & 0,594 & 0,678 & 2,472 & 0,877 & 0,001 \\
\hline M1 & 0,296 & 0,319 & 0,557 & 0,928 & 0,015 \\
\hline $\mathrm{X} 1 * \mathrm{M} 1$ & 0,018 & 0,020 & 4,051 & 0,936 & 0,000 \\
\hline $\mathrm{X} 2 * \mathrm{M} 1$ & 0,008 & 0,028 & 0,712 & 0,268 & 0,001 \\
\hline $\mathrm{X} 3 * \mathrm{M} 1$ & 0,022 & 0,025 & 3,672 & 0,886 & 0,000 \\
\hline
\end{tabular}

Primary Data, 2018

From Table 1. can be seen the value of the emotional intelligence coefficient of 0.545 , the value of the intellectual intelligence coefficient of 0.389 , the value of the spiritual intelligence coefficient of 0.594 , the regression coefficient of work experience is 0.296 , the regression coefficient value of emotional intelligence and work experience is 0.018 , the value the interaction regression coefficient between intellectual intelligence and work experience variables is 0.008 and the interaction regression coefficient value between the variables of spiritual intelligence and work experience is 0.022 , then the MRA regression equation is obtained as follows:

\section{$Y=5,032+0,545 X_{1}+0,389 X_{2}+0,594 X_{3}+0,296 M_{1}+0,018 X_{1} * M_{1}+0,008 X_{2} * M_{1}+0,022 X_{3} * M_{1}$}

\subsection{The Effects of Emotional Intelligence on Ethical Decisions}

Based on the test results of multiple linear regression analysis in Table 1, it shows the results that emotional intelligence has a positive and significant effect on the ethical decisions of tax consultants in the Bali Region. This is indicated by a significance value of 0,000 whose value is smaller than the specified level of significance $(\alpha=0.05)$ and has a regression coefficient of 0.075 so that the first hypothesis $(\mathrm{H} 1)$ is accepted ie emotional intelligence has a positive effect on the ethical decisions of tax consultants in the Region Bali.

The results of this study are consistent with previous research conducted by Tikollah (2006), which states that emotional intelligence has a positive effect on the ethical attitudes of accounting students. Similar to the research conducted by Lisda (2009) which states that emotional intelligence has a positive effect on auditor ethical behavior. As well as in line with research conducted by Mahadewi et al., (2015), which resulted that emotional intelligence has 
a positive effect on the ethical behavior of the public accounting profession at the Public Accounting Firm in the Bali Region.

Having emotional intelligence for a tax consultant will help him have high self-confidence in doing or doing a positive action, having the ability to understand, identify and manage emotions from negative heart pressures, able to maintain norms, values of integrity, and honesty and maintaining high responsibility for personal performance, in addition emotional intelligence can help a tax consultant in dealing with problems faced such as the demands of the task and problems of good relations with clients or other people, so that tax consultants can determine decisions appropriately and ethically.

\subsection{The Effect of Intellectual Intelligence on Ethical Decisions}

The second hypothesis (H2) states that intellectual intelligence has a positive effect on the ethical decisions of tax consultants in the Bali Region. Based on the test results of multiple linear regression analysis in Table 5.8, the results show that intellectual intelligence has a positive and significant effect on the ethical decisions of tax consultants in the Bali Region. This is indicated by a significance value of 0.001 whose value is smaller than the specified level of significance $(\alpha=0.05)$ and has a regression coefficient of 0.128 so that the second hypothesis $(\mathrm{H} 2)$ is accepted namely intellectual intelligence has a positive effect on the ethical decisions of tax consultants in the Region Bali.

The results of this study are consistent with previous research conducted by Tikollah (2006) which states that intellectual intelligence positively influences the ethical attitudes of accounting students. Similarly, the research conducted by Lisda (2009) states that intellectual intelligence has a positive effect on auditor ethical behavior. As well as in line with research conducted by Mahadewi et al., (2015), which resulted that intellectual intelligence had a positive effect on the ethical behavior of the public accounting profession at the Public Accountant Office in the Bali Region.

Having high intellectual intelligence for tax consultants will help him in showing knowledge about the problems faced, have the ability to analyze the conditions so that they can determine the right decisions, and identify problems that occur as a whole so that they can solve it to the root of the problem. Thus high intellectual intelligence will be able to direct a tax consultant to make ethical decisions in dealing with the tax problems faced when carrying out his profession.

\subsection{The Effect of Spiritual Intelligence on Ethical Decisions}

The third hypothesis (H3) states that spiritual intelligence has a positive effect on the ethical decisions of tax consultants in the Bali Region. Based on the test results of multiple linear regression analysis in Table 5.8, the results show that spiritual intelligence has a positive and significant effect on the ethical decisions of tax consultants in the Bali Region. This is indicated by a significance value of 0,000 whose value is smaller than the specified level of significance $(\alpha=0.05)$ and has a regression coefficient of 0.094 so that the third hypothesis (H3) is accepted namely spiritual intelligence has a positive effect on the ethical decisions of tax consultants in the Region Bali.

The results of this study are consistent with previous research conducted by Tikollah (2006), which states that spiritual intelligence has a positive effect on the ethical attitude of accounting students. Similar to the research conducted by Lisda (2009), which states that spiritual intelligence has a positive effect on auditor ethical behavior. As well as in line with research conducted by Mahadewi et al., (2015), which resulted that spiritual intelligence had a positive effect on the ethical behavior of the public accounting profession at the Public Accountant Office in the Bali Region.

By having high spiritual intelligence, a tax consultant can overcome scandals and problems regarding ethical dilemmas faced while carrying out his profession because spiritual intelligence can direct a tax consultant in playing his moral awareness to maintain self-integrity, be honest, and be able to overcome ethical dilemmas that occur in him so that the tax consultant can determine decisions ethically and not violate the professional code of ethics.

\subsection{The Work Experience Moderating the Effects of Emotional Intelligence on Ethical Decisions.}

The fourth hypothesis (H4) states that work experience strengthens the influence of emotional intelligence on the ethical decisions of tax consultants in the Bali Region. Based on the results of the regression in 1 shows a significance value of 0,000 whose value is smaller than the specified level of significance $(\alpha=0.05)$. This means that the work

Wiguna, I. P. I., \& Yadnyana, K. (2019). The role of working experience moderating the effect of emotional intelligence, intellectual intelligence, and spiritual intelligence on the ethical decision of tax consultants in Bali area. International Research Journal of Management, IT and Social Sciences, 6(3), 18-28. 
experience variable is a moderating variable. Positive direction on the regression coefficient indicates that work experience strengthens the influence of emotional intelligence on ethical decisions. This means that the ethical decisions of a tax consultant as an influence of emotional intelligence will be higher or more ethical if the tax consultant has work experience, thus the results of this study support the fourth hypothesis (H4).

The results of this study support the previous research conducted by Nadirsyah (2007) showing that auditor experience has a positive effect on auditor ethical decisions. Similarly, the research conducted by Harmana et al., (2017), which states that increasingly experienced tax consultants will tend to make increasingly ethical decisions

Theory of Cognitive Moral Development states that moral reasoning is the basis of ethical decision making. This theory suggests that a person's moral value will increase along with the many experiences faced during his lifetime. A tax consultant who has a lot of work experience will have good moral values by understanding and obeying the rules and established ethical standards, understanding the consequences of the actions taken, being able to work calmly because they have a level of knowledge and skills, so that the longer the experience of the tax consultant, the more likely they will be to make decisions that are more ethical. So that it can be concluded that work experience strengthens the level of emotional intelligence of tax consultants so that decisions made will be more ethical, with increasingly ethical decisions made, the ethical dilemma in the tax consultant can be avoided.

\subsection{The Work Experience Moderating the Effect of Intellectual Intelligence on Ethical Decisions.}

The fifth hypothesis (H5) states that work experience strengthens the influence of intellectual intelligence on the ethical decisions of tax consultants in the Bali Region. Based on the regression results in Table 1 shows a significance value of 0.001 whose value is smaller than the specified level of significance $(\alpha=0.05)$. This means that the work experience variable is a moderating variable. Positive direction on the regression coefficient indicates that work experience strengthens the influence of intellectual intelligence on ethical decisions. This means that the ethical decisions of a tax consultant as an influence of intellectual intelligence will be higher or more ethical if the tax consultant has work experience, thus the results of this study support the fifth hypothesis (H5).

The results of this study support the previous research conducted by Nadirsyah (2007) showing that auditor experience has a positive effect on auditor ethical decisions. Similarly, the research conducted by Harmana et al., (2017), which states that increasingly experienced tax consultants will tend to make increasingly ethical decisions

Theory of Cognitive Moral Development states that moral reasoning is the basis of ethical decision making. This theory suggests that a person's moral value will increase along with the many experiences faced during his lifetime. A tax consultant who has a lot of work experience will have good moral values by understanding and obeying the rules and established ethical standards, understanding the consequences of the actions taken, being able to work calmly because they have a level of knowledge and skills, so that the longer the experience of the tax consultant, the more likely they will be to make decisions that are more ethical. So that it can be concluded that work experience strengthens the level of intellectual intelligence of tax consultants so that decisions made will be more ethical, with increasingly ethical decisions made, the ethical dilemma in the tax consultant can be avoided.

\subsection{The Work Experience Moderating the Effects of Spiritual Intelligence on Ethical Decisions}

The sixth hypothesis (H6) states that work experience strengthens the influence of spiritual intelligence on the ethical decisions of tax consultants in the Bali Region. Based on the regression results in Table 1 shows a significance value of 0,000 whose value is smaller than the specified level of significance $(\alpha=0.05)$. This means that the work experience variable is a moderating variable. The positive direction on the regression coefficient indicates that work experience strengthens the influence of spiritual intelligence on ethical decisions. This means that the ethical decisions of a tax consultant as an influence of spiritual intelligence will be higher or more ethical if the tax consultant has work experience, thus the results of this study support the sixth hypothesis (H6).

The results of this study support the previous research conducted by Nadirsyah (2007) showing that auditor experience has a positive effect on auditor ethical decisions. Similarly, the research conducted by Harmana et al., (2017), which states that increasingly experienced tax consultants will tend to make increasingly ethical decisions.

Theory of Cognitive Moral Development states that moral reasoning is the basis of ethical decision making. This theory suggests that a person's moral value will increase along with the many experiences faced during his lifetime. A tax consultant who has a lot of work experience will have good moral values by understanding and obeying the rules and established ethical standards, understanding the consequences of the actions taken, being able to work calmly because they have a level of knowledge and skills, so that the longer the experience of the tax consultant, the more 
likely they will be to make decisions that are more ethical. So it can be concluded that work experience strengthens the level of spiritual intelligence of tax consultants so that decisions made will be more ethical, with the more ethical decisions made, the ethical dilemma in the tax consultant can be avoided.

\section{Conclusion}

Emotional intelligence has a positive effect on the ethical decisions of tax consultants in the Bali Region. This means that if the higher emotional intelligence possessed by a tax consultant in the Bali Region, the decisions made will be more ethical. Intellectual intelligence has a positive effect on the ethical decisions of tax consultants in the Bali Region. This means that if the higher intellectual intelligence possessed by a tax consultant in the Bali Region, the decisions made will be more ethical. Spiritual intelligence has a positive effect on the ethical decisions of tax consultants in the Bali Region. This means that if the higher spiritual intelligence possessed by a tax consultant in the Bali Region, the decisions made will be more ethical.

Work experience can moderate the relationship of emotional intelligence to the ethical decisions of tax consultants in the Bali Region. The results of the moderation test indicate a positive moderating relationship, this indicates that the ethical decisions of tax consultants in the Bali Region as the influence of emotional intelligence will be higher if tax consultants in the Bali Region have work experience. Work experience can moderate the relationship of intellectual intelligence to the ethical decisions of tax consultants in the Bali Region. The results of the moderation test indicate a positive moderating relationship, this shows that the ethical decisions of tax consultants in the Bali Region as the influence of intellectual intelligence will be higher if tax consultants in the Bali Region have work experience.

Work experience can moderate the relationship of spiritual intelligence to the ethical decisions of tax consultants in the Bali Region. The results of the moderation test indicate a positive moderating relationship, this indicates that the ethical decisions of tax consultants in the Bali Region as the influence of spiritual intelligence will be higher if the tax consultant in the Bali Region has work experience.

\section{Limitations}

This study has limitations on conclusions based on ethical decisions from registered tax consultants who have a license to practice in the Bali Region alone so that they cannot be generalized to all tax consultants in Indonesia. Future research can use this research as one of the references on ethical decisions of registered tax consultants who have practice permits in other regions.

\section{Further research}

This study used a self-assessment questionnaire (respondents rated themselves), so it was feared that respondents would only direct their responses in a positive direction. Future research can be developed through laboratory studies (experiments) and interviews to provide more convincing research results.

The coefficient of determination $\left(\mathrm{R}^{2}\right)$ of 0.824 shows that 82.4 percent of ethical decisions are influenced by variables of emotional intelligence, intellectual intelligence, spiritual intelligence, and work experience. Whereas $17.6 \%$ is influenced by other variables not presented in this research model. Subsequent research can also develop issues and phenomena from this study in the form of factors that can influence unethical decisions as well as influencing factors in the emergence of unethical behavior in the ethical dilemmas faced by tax consultants in Indonesia.

\section{Conflict of interest statement and funding sources}

The authors declared that they have no competing interest. The study was financed by personal funding.

Statement of authorship

The authors have a responsibility for the conception and design of the study. The authors have approved the final article.

\section{Acknowledgments}

The authors would like to acknowledge the editor of IRJMIS for their valuable time, support and advice in completing the current article.

Wiguna, I. P. I., \& Yadnyana, K. (2019). The role of working experience moderating the effect of emotional intelligence, intellectual intelligence, and spiritual intelligence on the ethical decision of tax consultants in Bali area. International Research Journal of Management, IT and Social Sciences, 6(3), 18-28. 


\section{References}

Abdurrahman, A., \& Laila Yuliani, N. (2012). Determinasi Pengambilan Keputusan Etis Auditor Internal (Studi Empiris Pada BUMN dan BUMD di Magelang dan Temanggung). Widya Warta, 35(2).

Adziem, F. (2016). Pengaruh moral reasoning, skeptisme profesional dan kecerdasan spiritual terhadap kualitas audit dengan pengalaman kerja auditor sebagai variabel moderating pada inspektorat provinsi sulawesi selatan.

Agustini, S., \& Herawati, N. T. (2013). Pengaruh kecerdasan intelektual, kecerdasan emosional dan kecerdasan spiritual terhadap sikap Etis mahasiswa S1 Akuntansi Universitas Pendidikan Ganesha Singaraja. JIMAT (Jurnal Ilmiah Mahasiswa Akuntansi) Undiksha, 1(1).

Arestanti, M. A., Herawati, N., \& Rahmawati, E. (2016). Faktor-Faktor Internal Individual dalam Pembuatan Keputusan Etis: Studi pada Konsultan Pajak di Kota Surabaya. Journal of Accounting and Investment, 17(2), 104117. https://doi.org/10.18196/1201

Atmadja, A. T., Saputra, S., \& Komang, A. K. (2014). The Effect Of Emotional Spiritual Quotient (ESQ) To Ethical Behavior In Accounting Profession With Tri Hita Karana Culture's As A Moderating Variable. Research Journal of finance and Accounting, 5(7), 187-197.

Devos, K. (2012). The impact of tax professionals upon the compliance behaviour of Australian individual taxpayers. Revenue Law Journal, 22(1), 31.

Doyle, E., Hughes, J. F., \& Summers, B. (2013). An empirical analysis of the ethical reasoning of tax practitioners. Journal of Business Ethics, 114(2), 325-339. https://doi.org/10.1007/s10551-012-1347-X

Durgut, M., Gerekan, B., \& Pehlivan, A. (2013). The impact of emotional intelligence on the achievement of accounting subject. International Journal of Business and Social Science, 4(13).

Dwijayanti, A. P. (2009). Pengaruh Kecerdasan Emosional, Kecerdasan Intelektual, Kecerdasan Spiritual, dan Kecerdasan Sosial terhadap Pemahaman Akuntansi. Skripsi Universitas Pembangunan Nasional "Veteran". Jakarta.

Farrastama, D. N., Asmony, T., \& Hermanto, H. (2019). Effect of emotional intelligence on counterproductive work behavior with job stress as an intervening variable. International Journal of Social Sciences and Humanities, 3(1), 14-25. https://doi.org/10.29332/ijssh.v3n1.248

Goleman, D. (2005). Working with emotional intelligence: kecerdasan emosi untuk mencapai puncak prestasi. Jakarta: PT Gramedia Pustaka Utama.

Harmana, M. D., Wirakusuma, M. G., \& Wirama, D. G. (2017). Pengaruh idealisme, pengalaman, dan komitmen profesional pada pembuatan keputusan etis konsultan pajak terdaftar di wilayah bali-nusa tenggara. E-Jurnal Ekonomi dan Bisnis Universitas Udayana, 3549-3578.

Jogiyanto, H. (2013). Metodologi Penelitian Bisnis Salah Kaprah dan Pengalaman-Pengalaman Edisi 6. Yogyakarta: BPFE.

Kohlberg, L. (1973). Stages and aging in moral development-Some speculations. The Gerontologist, 13(4), $497-502$. https://doi.org/10.1093/geront/13.4.497

Lisda, A. (2009). Pengaruh kemampuan intekltual, kecerdasan emosional, dan kecerdasan spiritual terhadap perilaku etis auditor serta dampaknya pada kenerja: studi empiris pada kantor akuntan publik di Jakarta.

Ljubomir, D., \& Angelina, T.-V. (2015). The Influence of Spiritual Intelligence on Ethical Behavior in Macedonia Organization. In International Symposium "System Thinking for A Sustainable Economy, Advancement in Economy and Managerial Theory and Practice.

Lucyanda, J., \& Endro, G. (2013). Faktor-Faktor Yang Memengaruhi Perilaku Etis Mahasiswa Akuntansi Universitas Bakrie. Media Riset Akuntansi, 2(2).

Mahadewi, D. P. L., Diatmika, I. P. G., SE, A., Si, M., ADIPUTRA, I. M. P., SE, S., \& Si, M. (2015). Pengaruh intelligence quotient (iq), dan emotional spiritual quotients (esq) terhadap perilaku etis profesi akuntan publik dengan locus of control sebagai variabel moderasi (studi empiris pada kantor akuntan publik di wilayah bali). JIMAT (Jurnal Ilmiah Mahasiswa Akuntansi) Undiksha, 3(1).

MIANINGSIH, Y. D. (2011). Pengaruh kecerdasan intelektual, kecerdasan emosional, dan kecerdasan spiritual terhadap intensi keperilakuan dalam pengambilan keputusan etis dengan locus of control sebagai variabel pemoderasi (Doctoral dissertation, Universitas Airlangga).

Nadirsyah. (2007). Pengaruh Perilaku Etis, Tekanan Ketaatan, Dan Pengalaman Auditor Terhadap Pengambilan Keputusan Etis Auditor BPKP Nangroe Aceh Darusallam. Jurnal Wafa, 2(2), 1-13.

Pitaloka, D. A., Wulandari, A., Basaruddin, T., \& Liliana, D. Y. (2017). Enhancing CNN with preprocessing stage in automatic emotion recognition. Procedia computer science, 116, 523-529. https://doi.org/10.1016/j.procs.2017.10.038 
Robbins, S. P. (1990). Organization Theory: Structures, Designs, And Applications, 3/e. Pearson Education India.

Soeprapto, M. C. K. (2016). Pengaruh Gender, Pengalaman Kerja, Gaya Kepemimpinan, Kecerdasan Emosional, Motivasi Dan Independensi Terhadap Pengambilan Keputusan Etis Akuntan Publik (Studi Empiris Di KAP Semarang) (Doctoral dissertation, Unika Soegijapranata).

Suadnyana, P. (2015). Pengaruh Kecerdasan Intelektual Pada Pemahaman Akuntansi Dengan Kecerdasan Emosi dan Kecerdasan Spiritual Sebagai Variabel Pemoderasi. Universitas Udayana.

Suardika, A. A. K. A., \& Suardika, A. A. K. A. (2015). Pengaruh Idealisme, Komitmen Profesional, dan Skeptisme Profesional pada Pembuatan Keputusan Etis Konsultan Pajak di Provinsi Bali (Doctoral dissertation, Universitas Udayana).

Sukriyah, I., Akram, \& Inapti, B. A. (2009). Pengaruh Pengalaman Kerja, Obyektifitas, Independensi, Integritas, dan Kompetensi Terhadap Kualitas Hasil Pemeriksaan. In Simposium Nasional Akuntansi (SNA) XII. Palembang.

Suraida, I. (2005). Pengaruh etika, kompetensi, pengalaman audit dan risiko audit terhadap skeptisisme profesional auditor dan ketepatan pemberian opini akuntan publik. Sosiohumaniora, 7(3), 186.

Tikollah, M. R., Triyuwono, I., \& Ludigdo, U. (2006). Pengaruh kecerdasan intelektual, kecerdasan emosional, dan kecerdasan spiritual terhadap sikap etis mahasiswa akuntansi (Studi pada Perguruan Tinggi Negeri di Kota Makassar Provinsi Sulawesi Selatan). Simposium Nasional Akuntansi, 9, 23-26.

Trevino, L. K. (1986). Ethical decision making in organizations: A person-situation interactionist model. Academy of management Review, 11(3), 601-617. https://doi.org/10.1007/S10551-01

Uyar, M., \& Özer, G. (2011). The ethical orientation and professional commitment: An empirical examination on Turkish accountants. African Journal of Business Management, 5(23), 10023-10037. https://doi.org/10.5897/AJBM10.1521

Wijayanti, G. L. (2012). Peran kecerdasan emosional dan kecerdasan spiritual dalam meningkatkan kinerja auditor(Doctoral dissertation, Widya Mandala Catholic University Surabaya).

Yani, F. (2011). Pengaruh Kecerdasan Intelektual, Kecerdasan Emosional, Kecerdasan Spiritual Terhadap Pemahaman Akuntansi. Jurnal Akuntansi Pendidikan. Universitas Riau.

Wiguna, I. P. I., \& Yadnyana, K. (2019). The role of working experience moderating the effect of emotional intelligence, intellectual intelligence, and spiritual intelligence on the ethical decision of tax consultants in Bali area. International Research Journal of Management, IT and Social Sciences, 6(3), 18-28. 


\section{Biography of Author}

\begin{tabular}{|l|l||}
\hline \hline I Putu Indra Wiguna was born on Denpasar. He finished his master study in Master \\
Accounting at Udayana University. He currently as Tax Staff at KJA Teddy \& Nanda \\
Denpasar. \\
Email: indra.wiguna89@gmail.com
\end{tabular}

